\title{
HUBUNGAN LATIHAN RELAKSASI OTOT PROGRESIF DENGAN KUALITAS TIDUR PADA LANSIA
}

\author{
Kiki Anggini ${ }^{1}$, Muliani Daeli ${ }^{2}$,Srimawarni Zai ${ }^{3}$ \\ Universitas Prima - Medan Fakultas Keperawatan dan Kebidanan \\ Program Studi Ilmu Keperawatan \\ e-mail: ${ }^{1}$ kikianggini0@gmail.com, ${ }^{2}$ mulyani.daeli123@gmail.com, ${ }^{3}$ sryzai1998@gmail.com
}

\begin{abstract}
Insomnia sleep disorders that distrupt a person's concentrartion causing insomnia or insufficient sleep, resulting in inefficient sleep. Cause stress if it continues to have an impact on anxiety, headaches, sexual decline in men, worsening vision, lack of concentration, fatigue, and anemia (Suci, 2014). The aim is to find out whether there is a relationship between progressive muscle relaxation exercises and sleep quality in the elderly at the Guna Budi Bakti Medan Foundation in 2020. This research uses quasy experiment method and uses one grub pretest posttest design, which uses two sample groups be interviewed before (pretest) and after (posttest) by filling out the questionnaire. Based on the results of the Wilcoxon signedrank test, that the value of $Z=-4,256^{b}$ with a $p$ value of 0,000 <0.05, the Ha is accepted and the Ho is rejected. It was concluded that there was an improvement in the quality of sleep in the elderly by doing progressive muscle relaxation exercises. Hopefully this research can improve the quality of nurses working in institutions capable of applying progressive muscle relaxation exercises in the elderly.
\end{abstract}

Keywords : Sleep Quality;Progressive Muscle Relaxation; Elderly

\begin{abstract}
ABSTRAK
Insomnia adalah gangguan tidur yang mengganggu konsentrasi seseorang menyebabkan sulit tidur atau tidak cukup tidur, sehingga waktu tidur tidak efesien. Menyebabkan stres apabila berkelanjutan berdampak pada kecemasan, sakit kepala, penurunan seksual pada pria, penglihatan memburuk, tidak konsentrasi, mudah lelah, dan anemia. Tujuan untuk mengetahui adakah hubungan latihan relaksasi otot progresif dengan kualitas tidur pada lansia di Yayasan Guna Budi Bakti Medan tahun 2020". Penelitian ini menggunakan metode Quasy Eksperiment dan memakai rancangan One Group Pretest Posttest, yaitu menggunakan 2 kelompok sampel diwawancara sebelum (pretest) dan sesudah (possttest) dengan mengisi kuisioner (Soekijo Notoatmojo,2017).Berdasarkan hasil perhitungan wilcoxon signedrank test, bahwa nilai $Z=-4.256$ dengan nilai p value 0,000<0,05 maka Ha diterima dan Ho ditolak. Disimpulkan bahwa terdapat peningkatan kualitas tidur pada lanjut usia dengan melakukan latihan relaksasi otot progresif. Semoga penelitian ini dapat meningkatkan kualitas perawat yang bekerja di panti mampu mengaplikasikan latihan relaksasi otot progresif pada lansia.
\end{abstract}

Kata Kunci : Kualitas Tidur; Otot Relaksasi Progresif; Lansia

\section{PENDAHULUAN}

\section{Latar Belakang}

Di masyarakat Indonesia lanjut usia di pandang sebagai realitis, banyak orang menyatakan lanjut usia pada umumnya mempunyai sifat yang konservatif dimana lansia susah menerima ide baru dan prilaku kembali seperti anak-anak. Populasi lansia di Indonesia kemungkinan akan mengalami penurunan dikarenakan adanya faktor-faktor beresiko yang mempengaruhi tingkat kualitas hidup lansia seperti resiko kesehatan, resiko biologi, resiko sosial dan resiko gaya hidup. Salah satu penurunan status kesehatan lansia lebih identik pada status kesehatan fisiknya. ${ }^{1}$

WHO dan Undang-undang Negara Indonesia pasal 1 ayat 2 no.13 tahun 1998 yaitu mengenai
Kesejahteraan Lansia, dimana usia lebih dari 60 tahun dalam priode ini terjadi penurunan pada fungsi organ tubuh seiring dengan berjalannya waktu. Lanjut usia adalah suatu proses dimana setiap individu mulai merasakan transformasi di hidupnya dengan gejala perubahan tingkah laku, menarik diri dari lingkungan, penurunan fungsi tubuh serta spiritual. Sehingga terjadi penurunan sistem imunitas tubuh, perubahan lingkungan serta terjadi perubahan fisiologi. 2,3

Penyakit yang dapat menurunkan kualitas hidup pada lansia terjadi karena faktor perilaku (40\% dialami oleh lansia) yaitu gangguan tidur (insomnia) dalam kurun waktu tertentu tergantung dari individunya sendiri. Tidur sangat bermanfaat bagi tubuh manusia terutama untuk fungsi organ tubuh, hal ini mampu mengembalikan energi tubuh. Selain itu juga waktu tidur yang sangat lama bisa menyebabkan tidak baik 
bagi tubuh seperti badan terlalu lemas, tidak bergairah saat bangun tidur. ${ }^{4} \quad$ Insomnia adalah gangguan tidur yang mengganggu konsentrasi seseorang menyebabkan sulit tidur atau tidak cukup tidur , sehingga waktu tidur tidak efesien. Sehingga dapat menyebabkan stres apabila berkelanjutan berdampak pada kecemasan, sakit kepala, penurunan seksual pada pria, penglihatan memburuk, tidak konsentrasi, mudah lelah, dan anemia. Adapun faktor yang dapat menimbulkan insomnia adalah stres, depresi, kegelisahan, kondisi fisik yang melemah, gaya hidup yang tidak sehat. Setiap tahunnya lansia yang mengalami gangguan tidur (insomnia) sedang sebanyak $20 \%-40 \%$ dan $17 \%$ nya mengalami masalah gangguan tidur berat. $5,6,7$

Perlu dilakukan penanganan gangguan masalah tidur (insomnia) untuk meningkatkan kualitas hidup lansia dan jumlah populasi penduduk lansia terus bertambah tiap tahunnya. Adapun cara untuk mengatasi gangguan tidur tanpa menggunakan obat adalah dengan latihan ROP (progressive muscle relaxation) yaitu menggunakan cara peregangan otot yang mampu meningkatkan kenyamanan, relaksasi dan psikologis. Dan rasa rileks inilah yang lansia butuhkan untuk meningkatkan kualitas tidurnya. Pengaruh dilakukannya latihan ROP mampu mengatasi kekakuan pada otot, menstabilkan tekanan darah, membangun emosi positif untuk mengendalikan stres, meningkatkan kebugaran jasmani, konsentrasi, dan memperbaiki kualitas tidur. Sedudah melakukan latihan relaksasi otot progresif akan memberikan dampak yang positif terhadap mengelolah stres, pikiran menjadi lebih tenang, meningkatkan konsentrasi, rasa nyaman, dan emosi dapat terkontrol. ${ }^{8,9}$

Latihan ROP adalah cara yang dapat mengendurkan masalah kekakuan pada otot bagian wajah sampai kaki dimana prosesnya yang singkat dan dinamis. Kegiatan ini dilakukan selama $\leq 30$ menit/hari diikuti arahan mengajarkan seseorang mengikuti urutan otot yang akan direlaksasikan. ${ }^{10}$

Survey awal peneliti ini dilakukan pada bulan Desember 2019 dan didapat data bahwasannya lansia diatas umur 60 tahun sebanyak 75 orang dan diantara lansia tersebut terdapat 20 orang yang mengalami masalah tidur dikarenakan lansia banyak mengalami stress tidak menjalani tugas atau kegiatan yang biasa dilakukan seperti masih muda. Banyak lansia yang susah tidak tidur mengkonsumsi terapi farmakologi. Sehingga peneliti tertarik mengambil judul "Hubungan terapi latihan relaksasi otot progresif dengan kulaitas tidur pada lansia di Panti Jompo Yayasan Guna Budi Bakti Medan Tahun2020”.

\section{METODE}

Penelitian ini menggunakan metode Quasy Eksperiment buat melihat ada hubungan atau tidak adanya hubungan antara relaksasi otot terhadap kualitas tidur pada lasia memakai rancangan One
Group Pretest Posttest, yaitu menggunakan 2 kelompok sampel diwawancara sebelum (pretest) dan sesudah (possttest) dengan mengisi kuisioner). Dimana keseluruhan lansia yang ada di Panti Jompo adalah populasi dengan jumlah total sebanyak 73 lansia, yang mencakup 31 lansia laki-laki dan 42 wanita pada tanggal 27 Desember 2019 - Januari 2020. Dan Sebagian dari subjek/objek populasi yang akan diteliti adalah sampel. sampelnya adalah lansia yang mengalami gangguan kualitas tidur. Teknik sampel yang diambil memakai non probability sampling degan teknikpurposive sampling yaitu pengambilan sampel berdasarkan kriteria khusus dari responden yang ada di lokasi.

Ciri-ciri yang dijadikan sampel yang harus di penuhi setiap anggota populasi.

1. Lansia usia 60 lebih.

2. Mampu mendengar dan berbicara

3. Lanjut usia dengan gangguan kualitas tidur

4. Bertempat tinggal di Panti Jompo guna budi bakti

5. Bersediamengikuti arahan dari peneliti.

6. Tidak mengkonsumsi obat-obatan farmakologi.

Ciri-ciri yang tidak bisa dijadikan sampel.

1. Lanjut usia di atas 90 tahun

2. Lanjut usia yang tidak bisa mendengar danberbicara

3. Lanjut usia dengan penyakit kronis

4. Lanjut usia yang mengkonsumsi obatobatan farmakologi.

Metode pengumpulan data padapenelitian ini memakai teknik wawancara bebas terpimpin, dimana responden diberi keleluasaan memahami pertanyaan sehingga memdapatkan jawaban yang diinginkan peneliti. Data primer adalah data yang didapat lansung dari responden dimana jumlah lanjut usia yang menderita gangguan kualitas tidur sebanyak 25 orang yang ada di panti jompo. Data sekunder adalah data dari sumber yang ada di Panti Jompo.

Aspek pengukuran ini dapat melihat kualitas tidur pada lanjut usia, untuk mengurangi gangguan kualitas tidur maka peneliti melakukan latihan ROP. Tujuannya ialah :

a. Meregangkan otot, mengurangi sakit leher, mengurangi sakittulang belakang, mengatasi kecemasan, menstabilkan tekanan.

b. Mencegah terjadinya kelainan ireguler denyut jantung.

c. Gelombang alfa meningkat ketika otak berada dalam kondisi diam namun tetap siaga ketika otak berada dalam kondisi diam namun tetap siaga.

d. Kemampuan untuk mengatasi stres 
membaik

e. Membangun emosi positif dari emosinegatif

f. Meregangkan otot, mengurangi sakit leher, mengurangi sakittulang belakang, mengatasi kecemasan, menstabilkan tekanan.

g. Mencegah terjadinya kelainan ireguler denyut jantung.

h. Gelombang alfa meningkat terjadi ketika otak berada dalam kondisi diam namun tetap siaga.

i. Kemampuan untuk mengatasi stresmembaik

j. Membangun emosi positif dari emosinegatif.

Penelitian ini juga menggunakan lembaran observasi untuk melihat perubahan dari relaksasi otot progresif dengan kualitas tidur pada lansia.

Analisa dalam penelitian ini adalah Analisis Univariat yaitu dilakukan dengan analisis distribusi frekuensi dan deskriptif untuk melihat karakteristik dari responden. Anilisis Bivariat memakai wilcoxon signedrank test untuk melihat signifikasi perbedaan tingkat kualitas tidur baik sebelum dilakukannya latihan dan setelah dilakukannya latihan.

\section{HASIL}

Pada hasil penelitian ini akan di paparkan tentang hubungan latihan ROP dengan kualitas tidur pada lansia. Kemudian akan kami sajikan dalam bentuk data univariat dan data bivariat. Dimana univariat termasuk jenis kelamin dan umur, sedangkan data bivariat termasuk kualitas tidur baik setelah ataupun sebelum diberikannya latihan ROP dalam bentuk susunan tabel.

\section{Data Univariat}

Tabel 3.1.

Distribusi Frekuensi Responden Berdasarkan Jenis Kelamin

\begin{tabular}{ccc}
\hline Jenis Kelamin & Jumlah & $\begin{array}{c}\text { Persentase } \\
\text { \% }\end{array}$ \\
\hline Laki-laki & 10 & $40 \%$ \\
Perempuan & 15 & $60 \%$ \\
\hline Total & $\mathbf{2 5}$ & $\mathbf{1 0 0} \%$ \\
\hline
\end{tabular}

Berdasarkan tabel 3.1 diatas menunjukkan bahwa responden lansia dipanti mayoritas perempuan sebanyak 15 orang $(60 \%)$ dan minoritas laki-laki sebanyak 10 orang (40\%).

Tabel 3.2

Distribusi Frekuensi Responden Berdasarkan
Usia

\begin{tabular}{ccc}
\hline Usia & Jumlah & $\begin{array}{c}\text { Persentase } \\
\text { \% }\end{array}$ \\
\hline usia 60-69 thn & 11 & $44 \%$ \\
usia 70-79 thn & 9 & $36 \%$ \\
usia 80-89 thn & 5 & $20 \%$ \\
\hline Total & $\mathbf{2 5}$ & $\mathbf{1 0 0 \%}$ \\
\hline
\end{tabular}

Tabel 3.2 diatas menunjukan responden usia 6069 tahun sebanyak 11 orang (44\%), usia 70-79 tahun 9 orang (36\%) dan usia $80-89$ tahun ada 5 orang $(20 \%)$.

\section{Data bivariat}

Analisa bivariat ini dilakukan untuk melihat peningkatan kualitas tidur pada lansia berdasarkan jenis kelamin dan umur baik sebelum dan sesudah dilakukannya latihan.

Tabel 3.3

Distribusi Frekuensi Berdasarkan Jenis Kelamin Sebelum (pre-test) Dilakukan Latihan Relaksasi Otot Progresif

\begin{tabular}{ccccc}
\hline Kualitas & \multicolumn{4}{c}{ Jenis Kelamin } \\
\cline { 2 - 5 } Tidur & \multicolumn{2}{c}{ Laki-laki } & \multicolumn{2}{c}{ Perempuan } \\
\cline { 2 - 5 } & F & \% & F & \% \\
\hline Baik & - & - & - & - \\
Cukup & 1 & $4 \%$ & 1 & $4 \%$ \\
Kurang & 4 & $16 \%$ & 4 & $16 \%$ \\
Buruk & 5 & $20 \%$ & 10 & $40 \%$ \\
\hline Total & $\mathbf{1 0}$ & $\mathbf{4 0 \%}$ & $\mathbf{1 5}$ & $\mathbf{6 0 \%}$ \\
\hline
\end{tabular}

Dari tabel 3.3 diatas sebelum dilakukannya latihan relaksasi otot progresif dapat dilihat bahwa kualitas tidur buruk pada laki-laki 5 orang (20\%), kurang 4 orang (16\%), cukup 1 orang (4\%) dari 10 lansia lakilaki dan mayoritas kualitas tidur buruk pada perempuan 10 orang (40\%), kurang 4 orang (16\%), cukup 1 orang (4\%) dari 15 lansia perempuan dengan jumlah total 25 responden.

Tabel 3.4

Distribusi Frekuensi Berdasarkan Usia Sebelum (pre-test) Dilakukan Latihan Relaksasi Otot Progresif Pada Lansia

\begin{tabular}{|c|c|c|c|c|c|c|}
\hline \multirow{3}{*}{$\begin{array}{c}\text { Kualitas } \\
\text { Tidur }\end{array}$} & \multicolumn{6}{|c|}{ Usia } \\
\hline & \multicolumn{2}{|c|}{ 60-69 } & \multicolumn{2}{|c|}{ 70-79 } & \multicolumn{2}{|c|}{ 80-89 } \\
\hline & $\mathbf{F}$ & $\%$ & $\mathbf{F}$ & $\%$ & $\mathbf{F}$ & $\%$ \\
\hline Baik & - & - & - & - & - & - \\
\hline Cukup & 2 & $\begin{array}{c}18.2 \\
\%\end{array}$ & - & - & - & - \\
\hline Kurang & 7 & $\begin{array}{c}63.6 \\
\%\end{array}$ & 1 & $9.1 \%$ & - & - \\
\hline Buruk & 2 & $\begin{array}{c}18.2 \\
\%\end{array}$ & 8 & $72.7 \%$ & 5 & $\begin{array}{c}45.5 \\
\%\end{array}$ \\
\hline
\end{tabular}




\begin{tabular}{ccccccc}
\hline Total & 11 & $\begin{array}{c}100 \\
\%\end{array}$ & 9 & $\begin{array}{c}81.8 \\
\%\end{array}$ & 5 & $\begin{array}{c}45.5 \\
\%\end{array}$ \\
\hline
\end{tabular}

Hasil tabel 3.4 kualitas tidur buruk pada lansia 6069 tahun 2 orang (18.2\%), kurang 7 orang (63.6\%), cukup 2 orang (18.2\%). Usia 70-79 kualitas tidur buruk 8 orang $(72.2 \%)$, kurang 1 orang $(9.1 \%)$, baik (0\%). Dan usia 80-89 tahun kualitas tidur buruk 5 orang $(45.5 \%)$ dari jumlah total 25 responden lansia.

Tabel 3.5

Distribusi Frekuensi Berdasarkan Jenis Kelamin Sesudah (post-test) Dilakukan Latihan Relaksasi Otot Progresif

\begin{tabular}{ccccc}
\hline Kualitas & \multicolumn{4}{c}{ Jenis Kelamin } \\
\cline { 2 - 5 } Tidur & \multicolumn{2}{c}{ Laki-laki } & \multicolumn{2}{c}{ Perempuan } \\
\cline { 2 - 5 } & $\mathbf{F}$ & $\mathbf{\%}$ & $\mathbf{F}$ & \% \\
\hline Baik & 8 & $32 \%$ & 9 & $36 \%$ \\
Cukup & - & - & 3 & $12 \%$ \\
Kurang & 1 & $4 \%$ & 2 & $8 \%$ \\
Buruk & 1 & $4 \%$ & 1 & $4 \%$ \\
\hline Total & $\mathbf{1 0}$ & $\mathbf{4 0 \%}$ & $\mathbf{1 5}$ & $\mathbf{6 0 \%}$ \\
\hline
\end{tabular}

Dari tabel 3.5 diatas setelah dilakukannya latihan ROP dilihat bahwa mayoritas tidur baik lansia berjenis kelamin laki-laki sebanyak 8 orang $(32 \%)$, kurang dan buruk masing-masing terdapat 1 orang (4\%) dari jumlah total 10 lansia laki-laki (40\%). Sedangkan kualitas tidur baik pada lansia berjenis kelamin perempuan sebanyak 9 orang $(36 \%)$, cukup 3 orang (12\%), kurang 2 orang $(8 \%)$ dan buruk 1 orang $(4 \%)$ dari jumlah total 15 lansia perempuan $(60 \%)$ dengan total keseluruhan responden 25 lansia.

Tabel 3.6

Distribusi Frekuensi Responden Kualitas Tidur Berdasarkan Usia Sesudah (post-test) Dilakukan Latihan Relaksasi Otot Progresif

\begin{tabular}{ccccccc}
\hline Kualitas & \multicolumn{6}{c}{ Usia } \\
\cline { 2 - 7 } Tidur & \multicolumn{2}{c}{$\mathbf{6 0 - 6 9}$} & \multicolumn{2}{c}{$\mathbf{7 0 - 7 9}$} & \multicolumn{2}{c}{$\mathbf{8 0 - 8 9}$} \\
\cline { 2 - 7 } & $\mathbf{F}$ & \% & F & \% & F & \% \\
\hline Baik & 11 & $100 \%$ & 7 & 63.3 & - & - \\
& & & \multicolumn{2}{c}{$\%$} & \\
Cukup & - & - & 2 & 18.2 & - & - \\
& & & & $\%$ & & \\
Kurang & - & - & - & - & - & - \\
Buruk & - & - & - & - & 5 & 45. \\
& & & & & & $5 \%$ \\
\hline Total & $\mathbf{1 1}$ & $\mathbf{1 0 0}$ & $\mathbf{9}$ & $\mathbf{8 1 . 8}$ & $\mathbf{5}$ & $\mathbf{4 5 .}$ \\
& & $\mathbf{\%}$ & & $\mathbf{\%}$ & & $\mathbf{5 \%}$ \\
\hline
\end{tabular}

Dari tabel 3.6 diatas setelah dilakukannya latihan relaksasi otot progresif dapat dilihat bahwa mayoritas kualitas tidur baik ada 11 orang $(100 \%)$ pada usia 60 69 tahun, usia 70-79 tahun ada 7 orang (63.3\%), Dan usia 80-89 tahun mayoritas kualitas tidur kurang sebanyak 3 orang (27.3\%), minoritas kualitas tidur buruk sebanyak 2 orang (18.2\%) dari jumlah total 25 responden lansia.

Tabel 3.7

Hasil Uji Perbandingan Hubungan Latihan Relaksasi Otot Progresif Dengan Kualitas Tidur

\begin{tabular}{cllll}
\hline $\begin{array}{c}\text { Kualitas } \\
\text { Tidur }\end{array}$ & Mean & $\begin{array}{c}\text { Std. } \\
\text { Deviation }\end{array}$ & \multicolumn{1}{c}{$\mathbf{Z}$} & $\begin{array}{c}\text { P } \\
\text { Value }\end{array}$ \\
\hline Pre - test & 3.51 & 653 & - & 0.000 \\
& & & 4.256 & \\
Post - & 1.60 & 1.000 & - & 0.000 \\
test & & & 4.256 & \\
\hline
\end{tabular}

Hasil dari tabel 3.7 diatas 25 orang lansia mengalami gangguan kualitas tidur berdasarkan hasil perhitungan wilcoxon signedrank test, bahwa nilai $\mathrm{Z}=-4.256^{\circ}$ dengan $p$ value $0,000<0,05$ maka Hipotesis alternatif (Ha) diterima dan Hipotesis Nol (Ho) ditolak. Disimpulkan bahwa terdapat peningkatan kualitas tidur pada lanjut usia dengan melakukan latihan relaksasi otot progresif.

\section{PEMBAHASAN}

Dari penelitian yang kami lakukan di Panti Jompo Guna Budi Bakti dimana responden berjenis kelamin perempuan 15 dan laki-laki 10 dari total keseluruhan 25 lansia. Usia lansia tersebut dari 60-90 tahun yang menjadi responden di panti jompo.

Lanjut usia merupakan individu yang telah berusia tahun atau lebih dimana mulai terjadi penurunan fungsi biologis, fungsi psikologis, dan penurunan sosial serta ekonomi yang berlansung secara terus menerus akibat penambahan usia yang terjadi secara alamiah dan dapat mempengaruhi status kesehatannya. Lanjut usia adalah sekelompok usia yang sudah menduduki tahap akhir dari hidupnya. Uraian umur meliputi usia 45-59 tahun (pertengahan), usia 60-74 tahun (lansia), usia 75-90 tahun (old), diatas 90 tahun (sangat tua). ${ }^{11,12}$

Keadaan ini dapat membawa dampak pada lansia seperti gampang cemas, yang bisa mempengaruhi waktu tidur. Lanjut usia sering terjaga oleh stimulus dari dalam ataupun dari luar, pergantian siklus dan perubahan hormon dapat menyebabkan durasi tidur menjadi singkat, waktu tidur berubah, sampai-sampai mengacu pada waktu tidur yang tidak efisien. Dan perubahan tersebut merupakan hal yang wajar selagi lansia masih mengalami durasi tidur baik, tetapi apabila mengalami gangguan kualitas tidur akan berdampak seperti insomnia sehingga sering terjadi dimana lansia mengalami cepat lelah, mudah tersinggung, kurang konsentrasi dan mengantuk pada siang hari 
dan mudah terserang penyakit. ${ }^{13}$

Durasi tidur yang baik berdurasi $>5$ jam dan suatu kebutuhan yang paling pokok bagi setiap makhluk hidup. Manusia mampu bertahan hidup tanpa makanan dalam kurun waktu 21 hari , namun jika tidak tidur dalam waktu yang sama dapat membuat seseorang mengalami gangguan psikosis. ${ }^{14}$

Dari hasil tabel 3.3 diatas sebelum dilakukannya latihan relaksasi otot progresif bedasarkanjenis kelamin dapat dilihat bahwa mayoritas tidur buruk pada laki-laki 5 orang (20\%),kurang4 orang (16\%), minoritas tidur cukup 1 orang $(4 \%)$ dari 10 lansia laki-laki dan mayoritas tidur buruk pada perempuan sebanyak 10 orang (40\%), kurang sebanyak 4 orang $(16 \%)$, minoritas tidur cukup sebanyak 1 orang $(4 \%)$ dari 15 lansia perempuan dengan jumlah total keseluruhan responden 25 lansia.

Pada penelitian tentang kualitas tidur menurut pendapat ( potter dan perry 2012) bahwa terdapat kaitan jenis kelamin terhadap kualitas tidur yang signifikan ( $\mathrm{P}$ value <0.05) dimana salah satu penyebab yang mempengaruhi tidur yaitu life style dan emosional. Didukung hasil penelitian oleh (Nugroho,2010) menyatakan bahwa perempuan lebih mungkin mengalami insomnia karena mekanisme koping adaptif rendahdalam mengelola stres atau tekanan sehingga tidak dapat memecahkan masalah secara efektif dibandingkan laki-laki. Gangguan secara psikologis dan jasmani dapat memicu perempuan lebih cepat mengalami cemas berlebihan jika terus menerus terjadi dapat menyebabkan individu sering mengalami gangguan tidur atau insomnia. ${ }^{15}$

Berdasarkan asumsi peneliti, Dimana perempuan lebih sering mengalami insomnia dikarenakan pertahanan dalam penyelesaian masalah lebih rendah dibandingkan laki-laki sehingga sulit memasuki tidur. Hal ini sesuai dengan hasil peneliti dimana nilai $p$ value 0.000 bahwa adanya pengaruh jenis kelamin terhadap kualitas tidur.

Dan pada tabel 3.4 sebelum dilakukannya latihan ROP berdasarkan usia dapat dilihat bahwa kualitas tidur buruk pada lansia usia 60-69 tahun ada 2 orang $(18.2 \%)$, kualitas tidur kurang sebanyak 7 orang (63.6\%), kualitas tidur cukup 2 orang (18.2\%) dan kualitas tidur baik sebanyak $(0 \%)$, sedangkan usia $70-79$ tahun tidur buruk 8 orang (72.2\%), kurang 1 orang $(9.1 \%)$, kualitas tidur cukup sebanyak $(0 \%)$ dan kualitas tidur baik sebanyak $(0 \%)$ dan diusia 80 89 tahun dimana diusia sebanyak 5 orang $(45.5 \%)$ mengalami kualitas tidur yang buruk, dari jumlah total keseluruhan 25 responden.

Hal ini didukung oleh penelitian (Nugroho,2010) dimana lanjut usia yang berumur diatas 60 tahun masih mengalami gangguan tidur dikarnakan dengan perubahan usia bisa menyebabkan durasi tidur berubah dan masih terbangun di tengah malam dan membutuhkan waktu untuk memulai tidur lagi. Lansia sering mengalami keluhan kesulitan tidur diwaktu malam dikarenakan mengalami kemunduran pada fungsi-fungsi tubuh. ${ }^{16}$

Menurt asumsi peneliti, masalah sulit tidur sering kali dirasakan oleh lansia 60 tahun ke atas atau lebih itu dikarenakan faktor fisiologis mengalami penurunan ini sama dengan hasil dari penelitian dimana lansia berusia diatas 60 tahun masih terbangun pada tengah malam dan susah memulai tidur dan cenderung keinginan untuk tidur di siang hari.

Penatalaksan untuk mengatasi gangguan kualitas tidur salah satunya yaitu secara non farmakologis dengan melakukan latihan progressive muscle relaxationyaitu dengan cara meregangkan otot lalu dilakukan relaksasi otot yang dapat digunakan untuk meningkatkan kenyamanan, relaksasi dan psikologis. kenyaman sangat diperlukan bagi lansia untuk meningkatkan kualitas tidurnya. Pengaruh sari latihan ROP mampu mengatasi otot-otot yang kaku, menstabilkan tekanan darah, membangun kemampuan untuk mengatasi stres, meningkatkan rasa kebugaran, konsentrasi, dan memperbaiki kualitas tidur pada lansia. ${ }^{8,9}$

Latihan relaksasi ini dilakukan selama seminggu dimana hari pertama diawali dengan mengisi kuesioner melalui teknik wawancara lansung dan dilakukannya latihan ROP. Dilakukan setiap hari yakni dimulai dari pukul 15.00 kurang lebih selama 15 - 30 menit/hari hingga selesai dan akan dilakukan intervensi pada hari terakhir. Dan rata-rata lansia sudah mulai memasuki durasi tidur yang cukup (5 - 6 jam) dan lama waktu untuk memulai tidur $<$ dari 30 menit (cukup) sehingga hal ini terbukti dari adanya perubahan durasi tidur sesudah melakukan latihan relaksasi otot progresif.

Dan pada tabel 3.5 setelah dilakukannya latihan ROP berdasarkan jenis kelamin dapat dilihat bahwa kualitas tidur baik pada lansia berjenis kelamin laki-laki sebanyak 8 orang $(32 \%)$, kualitas tidur cukup 0 orang $(0 \%)$, kualitas tidur kurang dan buruk masing-masing terdapat 1 orang $(4 \%)$ dari jumlah total 10 lansia laki-laki(40\%). Sedangkan kualitas tidur baik pada lansia berjenis kelamin perempuan sebanyak 9 orang (36\%), kualitas tidur cukup sebanyak 3 orang (12\%), kurang 2 orang (8\%) dan tidur buruk 1 orang (4\%) dari jumlah total 15 lansia perempuan $(60 \%)$.

Masalah yang sering terjadi pada kualitas tidur disebabkan oleh ketegangan otot pada saat seseorang sedang stress dan kecemasan berlebihan sehingga otot akan mengalami ketegangan. Dimana saat dilakukannya kegiatan fisik bisa membuat prilaku positif, mengurasi cemas, meningkatkan kualitas tidur dan dapat mengatasi depresi. ${ }^{17,18}$

Menurut asumsi peneliti, ternyata terdapat adanya hubungan antara latihan ROP dengan kualitas tidur lansia. Dimana lanjut usia yang mengalami gangguan kualitas tidur sudah mulai memasuki durasi tidur yang baik yaitu sekitar 7-8 jam. Dimana perlu melakukan latihan fisik agar mengurangi faktor 
emosional seperti stress dan cemas.

Pada tabel 3.6 sesudah dilakukannya latihan ROP berdasarkan usia 60-69 tahun dapat dilihat bahwa kualitas tidur baik 11 orang $(100 \%)$, pada umur 70-79 tahun ada 7 responden $(63.3 \%)$ kualitas tidur baik, cukup sebanyak 2 orang (18.2\%). Dan pada usia 80-89 ternayata kualitas tidur masih buruk terdapat 2 orang(18.2\%) dan kurang sebanyak 3 orang $(27.3 \%)$.

pada lansia yang berusia > 60 tahun perlu melakukan latihan relaksasi dan kegiatan fisik ataupun jasmani secara rutin agar dapat mempertahankan kebugaran jasmani dan menjaga kesehatan. Yaitu dengan melakukan latihan ROP dikombisanasikan memakai sirkulasi oksigen yang terkendali dan hubungan ransangan yang menstimuli respon relaksasi baik fisik ataupun psikologis. ${ }^{11}$

Menurut asumsi peneliti, setelah dilakukannya latihan ROP berdasarkan usia ada peningkatan kualitas tidur dimana mayoritas kualitas tidur baik berusia 60-69 tahun dan minoritas kualitas tidur baik pada usia 70-79 tahun dengan jumlah 7 orang. Itu dikarenakan pada usia 60-79 tahun lansia masih produktif dan mengikuti setiap terapi yang dilakukan oleh peneliti.

Dan terdapat hasil setelah dilakukannya latihan ROP ada perubahan tingkat kualitas tidur pada lansia dimana durasi tidur mengalami peningkatan sekitar 7 jam dimana hasil dari perhitungan wilcoxon signedrank didapat nilai $\mathrm{Z}=$ $4.256^{\mathrm{b}}$ dengan $\mathrm{P}$ Value 0.000 jadi Ha diterima dan Ho ditolak. Efek latihan relaksasi otot progresif dalam pemenuhan kebutuhan tidur dapat mengatur kegiatan sistem saraf tepi yang megatur fungsi viseral tubuh sehingga dapat untuk mempertahankan tidur serta meningkat durasi tidur setelah dilakukannya latihan ROP. ${ }^{19}$

Jika dilihat dari usia kualitas tidur pada lansia usia 60-79 tahun setelah dilakukannya latihan relaksasi otot progresif didapat hasil bahwasannya kualitas tidur baik. Sedangkan usia 80-89 tahun atau $>90$ tahun kualitas tidur baik sangat kecil kemungkinan dan masih mengalami gangguan tidur (insomnia) dikarenakan lansia usia 80-90 tidak produktif dalam mengikuti latihan yang diberikan disebabkan faktor fisik yang sudah melemah. Dimana semakin bertambahnya usia lansia itu lebih banyak menghabiskan waktu diatas tempat tidur sehingga frekuensi terbangun di tengah malam mengalami peningkatan. Tingkat kualitas tidur berawal dari prilaku seseorang, salah satu faktor dari dalam terpenuhinya kualitas tidur adalah dimana keadaan tubuh ketika bangun dari tidur terasa lebih bersemangat itu berarti waktu tidur tercukupi. a. Pada tabel 3.1 diatas responden perempuan 15 orang dan responden laki-laki 10 orang.

b. Pada tabel 3.2 diatas responden usia 60-90 sebanyak 25 lansia.

c. Pada tabel 3.3 diatas sebelum dilakukannya latihan relaksasi otot progresif berdasarkan jenis kelamin, kualitas tidur buruk mayoritas 10 responden perempuan dan minoritas 5 responden laki-laki.

d. Pada tabel 3.4 diatas sebelum dilakukannya latihan relaksasi otot progresif berdasarkan usia 60-90 tahun terdapat kualitas tidur buruk sebanyak 25 lansia.

e. Pada tabel 3.5 diatas sesudah dilakukannya latihan relaksasi otot progresif berdasarkan jenis kelamin terdapat kualitas tidur baik pada Pr 9 responden dan Lk 8 responden.

f. Pada tabel 3.6 diatas sesudah dilakukannya latihan relaksasi otot progresif berdasarkan usia 60-90 tahun terdapat kualitas tidur baik sebanyak 18 lansia.

\section{SARAN}

a. Bagi Responden Diharapkan kepada responden dapat memahami fungsi latihan relaksasi otot ptogresif untuk meningkatkan durasi tidur pada lansia.

b. Bagi Peneliti Selanjutnya

Untuk seterusnya mohon dapat menggunakan hasil dari penelitian ini sebagai bahan pertimbangan ketika smenyusun skripsi.

c. Bagi LahanPenelitian

Diharapkan pada perawat yang bekerja di panti mampu mengaplikasikan latihan relaksasi otot progresif pada lansia.

\section{DAFTAR PUSTAKA}

1. Stanhope, M., \& Lancaster, J. Public health nursing population centered health care in the community (9th Ed.). Missouri: Elsevier (2016).

2. WHO WHOQOL Spirituality, religiousness and personal beliefs (SRPB) field-test instrument. Geneva:WHO (2012).

3. Maheswari, S. K., Tak1, G. S., \& Kau, Manpreet. (2016). Effectivenes Of Progresive Muscle Relaxation Technique On Anxiety Among Elderly. International Journal of Therapeutic Applications. Vol. 32 hal 48-54 
4. Mustika, ER, dkk. Pengaruh Membaca AlQur'an Terhadap Kualitas Tidur Lansia Di Posyandu Lansia Matahari Senja Kelurahan Kedungdoro[skripsi]. Surabaya .2014 (cited 28 April 2015)

5. Viska, Suci, Ramadhani Hubungan Stres Dengan Kejadian Insomnia Pada Lansia Di Panti Sosial Tresna Werdha Kasih Sayang $\mathrm{Ibu}$ Batusangkar[Skripsi] Universitas Muhammadiah Sumatera Barat (2014). Diakses pada tanggal 27 Mei 2015.

6. Sohat, F. Hubungan Tingkat Kecemasan Dengan Insomnia Pada Lansia Di Balai Penyantunan Lanjut Usia Senja Cerah Paniki Kecamatan MapangetManado; (2014).

7. Kurniawan, Tommy. Faktor-Faktor Yang Mempengaruhi Gangguan Tidur (Insomnia) Pada Lansia Di Panti Tresna Werdha Kabupaten Magetan [internet]. Medscape 2012 (cited 29 januari 2014) Availible from http://scholar.google.com/scholar.

8. Gemilang, J, Buku Pintar Manajemen stres dan Emosi. Yogyakarta : Mantra Books (2013).

9. Dhyani, D., Sen, S., \& Raghumahanti, R. Effect Of Progressive Muscular Relaxation On Stress And Disability In Subjects With Chronic Low Back Pain. Journal Of Nursing And Health Science. Vol. 4 No. 1 (2015).

10. Marks,I. Tracey. Master your Sleep, Proven Methode Simplied. USA: Bascom Hills Publish Group(2011).

11. Maryam , S., Ekasari., F.M, Rosidawati., Jubaedi, A., \& Batubara, I. Mengenal Usia Lanjut dan Perawatannya. Salemba medika. Jakarta : (2008).

12. Nugroho,W. (2000). Keperawatan gerontik. Jakarta : EGC.

13. Aswin, etal Gangguan tidur pada usia lanjut [internet]. Mescape 2008 (cited 15 februari, 2010). Availible from http://202.59.161.223/article/58/69.html?lang =en

14. Adesia,Veronica. Gangguan tidur [internet]. Medscape (2009). (cited 15 Februari 2010). Available from http://www.emedicinehealth.com/gangguanti dur/article.hmt

15. Nugroho, (2010), Keperawatan Gerontik dan Geriatrik. Jakarta : Penerbit Buku Kedokteran EGC.

16. Perry \& Potter, Buku Ajar Fundamental Keperawatan,: Konsep, Proses, Dan Praktik. Jakarta: EGC; 2009.

17. Stanley, M dan Beare, P.G. Buku Ajar Keperawatan Gerontik Edisi 2 EGC. Jakarta; (2006).

18. Sumedi, T . Pengaruh Senam Lansia Terdapat Penurunan Skala Insomnia pada
Lansia di Panti Wredha Dewantara Cilacap, Jurnal Sudirman Poltekes Depkes Purwokwerto. Vol : 5(1) hal 13-20

19. Conrad, A., \& Roth, W. T. Muscle relaxation therapy for anxiety disordes: It works but how? Journal of Anxiety Disorders, 21, 243264 (2007). 